\title{
The realization
}

\section{of the human right to food:} preliminary remarks on assessing food security

\section{Realizacja prawa człowieka do żywności: uwagi wstępne na temat oceny} bezpieczeństwa żywnościowego

\section{Introduction}

The International Monetary Fund states that the world economy is facing a deep recession with the ongoing impact of COVID-19 (IMF, 2020). The current pandemic resulting in a socio-economic crisis, definitely has an impact on global poverty and food and nutrition insecurity in short and medium term (Sachs et al., 2020, p. 4). Even if the recession lasts for a short time, inadequate nutrition could have far-reaching implications, especially for child health and human development. In recent years, there have been several major challenges facing the global agricultural and food sector, and they are becoming even greater at this difficult time. These include, inter alia, (i) ensuring food security in the age of growing food demand considering the current trends of growing human population, incomes and intensive urbanization, (ii) improving nutrition security in the times of continuing growth of an obesogenic environment and of spreading the phenomenon of hidden hunger; and another increase in the number of both under- and over-nourished people. COVID-19 has been shrinking the global economy, disrupting markets and livelihoods and the ability of the world's most vulnerable to earn an income and feed their families. Millions of people are at risk of falling deeper into poverty and hunger from this crisis, including the poor, women and children, those living in fragile or conflict-affected states, refugees, minorities, and the unsheltered, particularly those living in Sub-Saharan Africa and South Asia (Global Nutrition Report, 2020b, p. 10; Laborde et al., 2020, p. 501). Furthermore, the ongoing pandemic could cause shifts in consumer 
demand toward cheaper and less nutritious foods (Laborde et al., 2020, p. 500; E.I.T. Food, 2020, p. 9). The fact that in 2020 a large part of people in OECD countries was under some form of lockdown has increased the economic and social inequalities within the countries and has had an impact on increasing the number of malnourished people including the overweight/obese and/or the underweight (Sachs et al., 2020, p. 12, 37). In response to the pandemic, about $10 \%$ of the countries worldwide imposed temporary restrictions on export of certain foodstuffs (mainly staple foods) which contributed to reduced global food supply and caused rapid world food prices increases (Hepburn et al., 2020, pp. 1-4; Espitia, Rocha, \& Ruta, 2020, pp. 1-4). The COVID-19 pandemic contributed to the largest single-year increase in global hunger in decades. In 2020, there were 161 million food-insecure people more than in 2019 (FAO, 2021, p. 1). It is worth adding that long-lasting working from home and remote learning have also had a positive impact on food-related consumer behaviour, particularly in developed countries. Over the pandemic a significant growth of consumers' interest in healthy and sustainable diet was indicated (E.I.T. Food, 2020, pp. 3-13; The Guardian, 2020). With people spending more time at home there has been a significant rise in people enjoying cooking and eating regular meals at home (Acosta Market Research, 2020; E.I.T. Food, 2020, p. 13; Grunert et al., 2022).

The performance level of food and nutrition security (FNS) in the region, country or household determine the quality of life in society. The primary function of the state is to improve the life quality of its citizens. In many countries, combating hunger and malnutrition is a legally binding human rights obligation (UN OHCHR, 2010, p. 1). According to Osiatyński (2011, p. 166), human rights are universal moral laws of a basic nature, belonging to every individual in their contacts with the state. Grounded in human dignity, they are vested in every person, regardless of acts of law (Kowalski, 2020, p. 235). Kalinowski (2019, pp. 461-462) has highlighted difficulties in understanding the notion of human dignity, which might be also perceived as an opportunity to create an open dialogue about the scope of human rights protection. The Food and Agriculture Organization of the United Nations (FAO) has stated that FNS exists when

all people at all times have physical, social and economic access to food, which is safe and consumed in sufficient quantity and quality to meet their dietary needs and food preferences, and is supported by an environment of adequate sanitation, health services and care, allowing for a healthy and active life (CFS, 2012b, p. 7). 
This definition is in accordance with the Human Right to Adequate Food and the fundamental right of everyone to be free from hunger, the concept which has been integral to FNS since the World Food Summit of 1996. The right to food places legal obligations on states to overcome hunger and malnutrition and realize FNS for all (UN OHCHR, 2010, p. 4). FNS is a public good that market mechanism is not able to supply effectively, therefore activity of the state to satisfy the demand for this good appears necessary (Kowalska, 2019, pp. 251-263). The society expects the state to ensure FNS, given that the state as a regulator, creator and guardian of a social and economic order has no counterpart in the global system. The aim of this article is to analyze the realization of the right to food in different countries and to identify challenges of interpreting and then acting upon the value of the Global Food Security Index (GFSI).

\section{Research background}

\subsection{The right to (adequate) food}

Human rights have been experiencing a cautious renaissance recently. People in many parts of the world (excluding North Korea and Western Sahara) have easy access to new scientific knowledge and new information thus the global society is becoming more aware of the existing human rights, particularly since the issue of human rights has been a hot topic. In 2018 over a half (50.76\%) of the world population used the Internet (WB, 2021). However, in the era of mass access to the Internet, it is very difficult to find a clear, full, accurate and unbiased information on any topic.

Human rights are subject to multi-level protection (international, regional, national level). The protection of human rights at the international level has been set out in, inter alia, the Charter of the United Nations and the Universal Declaration of Human Rights (UDHR). At the regional level, such protection is provided, among others, in the European Convention on Human Rights, the American Convention on Human Rights, and the African Charter on Human and People's Rights. Regional systems for the protection of human rights rely on institutions which provide at least a minimum level of protection, i.e. the Council of Europe and the European Court of Human Rights, the Organization of American States (OAS) and the Inter-American Court of Human Rights, the African Commission on Human and People's Rights and the African Court of Human and People's Rights. Regional systems play a complementary role to the global system, in accordance with the following motto: "think globally but act regionally"; regional mechanisms are the developers of the global human rights project in particular regions (Heyns, 
\& Killander, 2011, p. 528; Kowalski, 2020, p. 235). The protection of human rights is also ensured in the national legislation including the constitution.

The issue of freedom from want was first raised at the January 1941 United States President Franklin D. Roosevelt's speech. He proposed four fundamental freedoms that all the people in the world ought to enjoy: (1) freedom of speech; (2) freedom of worship; (3) freedom from want; (4) freedom from fear. Freedom from want, translated into world terms, means economic understandings which will secure to every nation a healthy peacetime life for its inhabitants - everywhere in the world (Roosevelt, 1941).

Article 25(1) of the 1948 Universal Declaration of Human Rights (UDHR), adopted by the United Nations General Assembly (UN GA), states that: "Everyone has the right to a standard of living adequate for the health and well-being of himself and of his family, including food, clothing, housing and medical care and necessary social services" (UN, 2021). UDHR was the first document of an international nature to explicitly mention the right to food. It was a manifesto against great harm that human beings experienced during the Second World War (see Srogosz, 2020, p. 1-37).

Article 11 of the 1966 International Covenant on Economic, Social and Cultural Rights (ICESCR) ${ }^{1}$, a multilateral treaty adopted by UN GA, states that "the States Parties to the present Covenant recognize the right of everyone to an adequate standard of living for himself and his family, including adequate food, clothing and housing, and to the continuous improvement of living conditions" (UN OHCHR, 2021b). This article also refers to the involvement of the States in the realization of this right, recognizing the essential importance of international cooperation based on free consent. Under article 2 of ICESCR, the States have obligations to take steps to realize rights recognized in it, including the right to food, individually as well as through international assistance and cooperation. The Covenant has recognized several measures for realization of the right to adequate food including improving the methods of production, conservation and distribution of food by making full use of technical and scientific knowledge (see Table 1). Isn't it surprising that the measures are still relevant today? However, widespread socio-political turmoil and global economy turbulences have led to further distancing from the desired objective of ensuring FNS for all. The scope of international regulation relating to the protection of the right to (adequate) food is very wide (Table 1), which shows that this issue has been of global importance and of vital importance for human survival.

$1 \quad$ The International Covenant on Economic, Social and Cultural Rights of 1966, together with the Universal Declaration of Human Rights of 1948 and the International Covenant on Civil and Political Rights of 1966, make up the International Bill of Human Rights being a primary international legal source of human rights. The Covenant entered into force in 1976 (Council of Europe, 2021). 
Table 1. International law documents regarding the right to food

\begin{tabular}{|c|c|c|}
\hline Document name & Provision relating to the right to food & $\begin{array}{c}\text { Area } \\
\text { of application }\end{array}$ \\
\hline $\begin{array}{l}\text { Universal Declaration } \\
\text { of Human Rights of } 10 \\
\text { December 1948, Paris }\end{array}$ & $\begin{array}{l}\text { Art. } 25 \\
\text { 1. Everyone has the right to a standard of living } \\
\text { adequate for the health and well-being of himself } \\
\text { and of his family, including food, clothing, housing } \\
\text { and medical care and necessary social services, and } \\
\text { the right to security in the event of unemployment, } \\
\text { sickness, disability, widowhood, old age or other lack of } \\
\text { livelihood in circumstances beyond his control }\end{array}$ & $\begin{array}{l}\text { Applies to } 193 \\
\text { countries }\end{array}$ \\
\hline $\begin{array}{l}\text { Convention for the } \\
\text { Amelioration of the } \\
\text { Condition of the } \\
\text { Wounded and Sick in } \\
\text { Armed Forces in the } \\
\text { Field of } 12 \text { August } \\
\text { 1949, First Geneva } \\
\text { Convention }\end{array}$ & $\begin{array}{l}\text { Art. } 32 \\
{[\ldots] \text { The Parties to the conflict shall secure to this per- }} \\
\text { sonnel, while in their power, the same food, lodging, } \\
\text { allowances and pay as are granted to the corresponding } \\
\text { personnel of their armed forces. The food shall in any } \\
\text { case be sufficient as regards quantity, quality and varie- } \\
\text { ty to keep the said personnel in a normal state of health }\end{array}$ & $\begin{array}{l}196 \text { State Parties } \\
\text { have ratified the } \\
\text { Convention }\end{array}$ \\
\hline $\begin{array}{l}\text { Geneva Convention } \\
\text { Relative to the Treat- } \\
\text { ment of Prisoners } \\
\text { of War of } 12 \text { August } \\
\text { 1949, Third Geneva } \\
\text { Convention }\end{array}$ & $\begin{array}{l}\text { Art. } 32 \\
\text { The evacuation of prisoners of war shall always } \\
\text { be effected humanely and in conditions similar to } \\
\text { those for the forces of the Detaining Power in their } \\
\text { changes of station. The Detaining Power shall supply } \\
\text { prisoners of war who are being evacuated with suff- } \\
\text { cient food and potable water, and with the necessary } \\
\text { clothing and medical attention. [...] } \\
\text { The Detaining Power shall supply prisoners of war } \\
\text { during transfer with sufficient food and drinking } \\
\text { water to keep them in good health, likewise with the } \\
\text { necessary clothing, shelter and medical attention }\end{array}$ & $\begin{array}{l}196 \text { State parties } \\
\text { have ratified the } \\
\text { Convention }\end{array}$ \\
\hline $\begin{array}{l}\text { International Cove- } \\
\text { nant on Economic, } \\
\text { Social and Cultural } \\
\text { Rights of } 16 \text { December } \\
\text { 1966, New York }\end{array}$ & $\begin{array}{l}\text { Art. } 11 \\
\text { 2. The States Parties to the present Covenant, recog- } \\
\text { nizing the fundamental right of everyone to be free } \\
\text { from hunger, shall take, individually and through } \\
\text { international cooperation, the measures, including } \\
\text { specific programmes, which are needed: } \\
\text { (a) To improve methods of production, conserva- } \\
\text { tion and distribution of food by making full use of } \\
\text { technical and scientific knowledge, by disseminating } \\
\text { knowledge of the principles of nutrition and by } \\
\text { developing or reforming agrarian systems in such } \\
\text { a way as to achieve the most efficient development } \\
\text { and utilization of natural resources } \\
\text { (b) Taking into account the problems of both food- } \\
\text {-importing and food-exporting countries, to ensure } \\
\text { an equitable distribution of world food supplies in } \\
\text { relation to need }\end{array}$ & $\begin{array}{l}170 \text { countries have } \\
\text { ratified the Cove- } \\
\text { nant (countries of } \\
\text { Europe, Australia } \\
\text { and Oceania, South } \\
\text { America, North } \\
\text { America (other } \\
\text { than USA), Africa } \\
\text { (other than Sudan } \\
\text { and Somalia), Asia } \\
\text { (other than Iran) }\end{array}$ \\
\hline
\end{tabular}




\begin{tabular}{|c|c|c|}
\hline $\begin{array}{l}\text { Additional Protocol } \\
\text { to the American } \\
\text { Convention on Human } \\
\text { Rights in the Area of } \\
\text { Economic, Social and } \\
\text { Cultural Rights ("Pro- } \\
\text { tocol of San Salvador") } \\
\text { of } 17 \text { November 1988, } \\
\text { San Salvador }\end{array}$ & $\begin{array}{l}\text { Art. } 12 \\
\text { Right to Food } \\
\text { 1. Everyone has the right to adequate nutrition which } \\
\text { guarantees the possibility of enjoying the highest level } \\
\text { of physical, emotional and intellectual development } \\
\text { 2. In order to promote the exercise of this right and eradi- } \\
\text { cate malnutrition, the States Parties undertake to improve } \\
\text { methods of production, supply and distribution of food, } \\
\text { and to this end, agree to promote greater international } \\
\text { cooperation in support of the relevant national policies }\end{array}$ & $\begin{array}{l}\text { Applies to } 24 \text { OAS } \\
\text { countries }\end{array}$ \\
\hline $\begin{array}{l}\text { Convention on the } \\
\text { Rights of the Child of } \\
20 \text { November 1989, } \\
\text { New York }\end{array}$ & $\begin{array}{l}\text { Art. } 24 \\
{[\ldots] 2 \text {. States Parties shall pursue full implemen- }} \\
\text { tation of this right and, in particular, shall take } \\
\text { appropriate measures: } \\
{[\ldots] \text { c) To combat disease and malnutrition, including }} \\
\text { within the framework of primary health care, through, } \\
\text { inter alia, the application of readily available technology } \\
\text { and through the provision of adequate nutritious foods } \\
\text { and clean drinking-water, taking into consideration the } \\
\text { dangers and risks of environmental pollution [...] } \\
\text { Art. } 27 \\
{[\ldots . .] \text { 3. States Parties, in accordance with national condi- }} \\
\text { tions and within their means, shall take appropriate mea- } \\
\text { sures to assist parents and others responsible for the child } \\
\text { to implement this right and shall in case of need provide } \\
\text { material assistance and support programmes, particularly } \\
\text { with regard to nutrition, clothing and housing }\end{array}$ & $\begin{array}{l}\text { Applies to all coun- } \\
\text { tries of the world } \\
\text { except for USA and } \\
\text { Western Sahara }\end{array}$ \\
\hline $\begin{array}{l}\text { Protocol Additional to } \\
\text { the Geneva Conven- } \\
\text { tions of } 12 \text { August 1949, } \\
\text { and Relating to the } \\
\text { Protection of Victims } \\
\text { of Non-International } \\
\text { Armed Conflicts of } 8 \\
\text { June 1977, Geneva }\end{array}$ & $\begin{array}{l}\text { Art. } 14 \\
\text { Starvation of civilians as a method of combat is pro- } \\
\text { hibited. It is therefore prohibited to attack, destroy, } \\
\text { remove or render useless, for that purpose, objects } \\
\text { indispensable to the survival of the civilian popu- } \\
\text { lation, such as foodstuffs, agricultural areas for the } \\
\text { production of foodstuffs, crops, livestock, drinking } \\
\text { water installations and supplies and irrigation works }\end{array}$ & $\begin{array}{l}\text { The protocol has } \\
\text { been ratified by } 168 \\
\text { countries, except } \\
\text { for USA, India, } \\
\text { Pakistan, Turkey, } \\
\text { Iran, Iraq, Syria and } \\
\text { Israel }\end{array}$ \\
\hline
\end{tabular}

Source: own preparation based on (ICRC, 2021a, b, c; OAS, 2021; UN, 2021; UN OHCHR, 2021a, b).

In 1985 the Committee on Economic, Social and Cultural Rights was established to monitor implementation of ICESCR by its States Parties. These parties have had to submit regular reports on their compliance with the Covenant to the Committee. In 1999 the Committee affirmed in the General Comment No 12 that "the right to adequate food is indivisibly linked to the inherent dignity of the human person and is indispensable for the fulfillment of other human rights". This document has indicated that the right to adequate food, like any other human 
right, imposes three types or levels of obligations on States Parties: the obligations to respect, to protect and to fulfill (CESCR General Comment No. 12, 1999). Thus, the realization of the right to food consists of respecting, protecting and fulfilling (facilitating and providing). The right to food requires the States to provide an enabling environment in which FNS is ensured. The States implement their existing obligations in relation to the right to food, inter alia, by (a) running a successful food and agricultural policy; (b) updating food law; (c) improving environmental policy to prevent destroying sources of food; $(\mathrm{d})$ taking into account their international legal obligations regarding the right to food when entering into agreements with other States or with international organizations; (e) developing nutrition programs; (f) taking the legislative and other measures to protect people, especially children, from advertising and promotions of unhealthy food; $(\mathrm{g})$ providing food assistance for the most deprived (Sachs et al., 2020, pp. 17-19).

The right to food has been also described by the Office of the United Nations High Commissioner for Human Rights (UN OHCHR) as follows: "the right to adequate food is realized when every man, woman and child, alone or in community with others, has physical and economic access at all times to adequate food or means for its procurement" and by the UN Special Rapporteur on the right to food as

the right to have regular, permanent and free access, either directly or by means of financial purchases, to quantitatively and qualitatively adequate and sufficient food corresponding to the cultural traditions of the people to which the consumer belongs, and which ensures a physical and mental, individual and collective, fulfilling and dignified life free of fear (UN OHCHR, 2010, p. 2).

Hospes and van der Meulen (2009, p. 22) have suggested that the right to adequate food is realized when people have access to food that: (1) provides sufficient nutritional value and micronutrients for a person to lead a healthy and active life, (2) is free of hazardous substances, and (3) is acceptable within a given culture. It is worth emphasizing that the authors refer not only to nutritional value of food and food safety, but also to the cultural context of the person concerned. Sachs et al. (2020, pp. 4-5) point out that "the right to food" and "food security" are two different terms, and consider the right to food as "a human right recognized under international law that provides entitlements to individuals to access to adequate food and to the resources that are necessary for the sustainable enjoyment of food security." Although, since the prices of goods and services and income levels have been identified as key factors for FNS (Pangaribowo, Gerber, \& Torero, 2013, p. 22), central to implementing the state's obligation to 
respect, protect and fulfill the right to food is a continuous improvement of the well-being of people and fostering entrepreneurship.

\subsection{Food security and nutrition security (a review of definitions)}

The definition of food security has changed since the first introduction of the concept in the early 1940 when the perspective of food-supply to ensure that all people everywhere have enough food to eat dominated. The basic concepts underlying the terms "food security" and "nutrition security" were articulated in 1943. This year forty-four governments met in Hot Springs, Virginia, USA, to consider the goal of "freedom from want" in relation to food and agriculture. They concluded that "freedom from want" meant a secure, adequate and suitable supply of food for every human being, where "secure" referred to the accessibility of the food, "adequate" referred to the quantitative sufficiency of the food supply and "suitable" referred to the nutrient content of the food supply (CFS, 2012a, p. 4).

The World Food Summit of 1996 defined food security as "a state when all people, at all times, have physical and economic access to sufficient, safe and nutritious food that meets their dietary needs and food preferences for an active and healthy life" (Pinstrup-Andersen, 2009, p. 5). Physical availability of food is determined by production output, stock levels and trade dynamics, and economic and physical access to food is determined by the ability to buy food e.g. ratio of prices to income, and accessible marketing channels (Manning, 2020).

The UN World Food Programme (WFP, 2006, p. 20) has expressed food security as "a condition that exists when all people at all times are free from hunger - that is, they have sufficient nutrients (protein, energy, and vitamins and minerals) for fully productive, active and healthy lives." Food security includes four elements: (1) availability (the supply of food in an area); (2) access (a household's ability to obtain that food); (3) utilization (a person's ability to select, take-in and absorb the nutrients in the food); and (4) vulnerability (the physical, environmental, economic, social and health risks that may affect availability, access and use). Thus, WFP has included nutritional and wider risk criteria in the definition of food security. Food security is achieved by people acquiring a safe, adequate and appropriate food supply. 'Safe' is the absence of hazard; 'adequate' is sufficient in both calories and nutrients; 'appropriate' relates to taste and ethnicity (especially important when offering food aid to other countries in response to emergencies, i.e., using readily available food).

FAO distinguishes four pillars of food security: (1) availability (is the supply of food adequate?); (2) access (can people obtain the food they need?); (3) utilization 
(do people have enough intake of nutrients?); and (4) stability (can people access food at all times?) (CFS, 2014, p. 2). The COVID-19 pandemic is affecting all of them, e.g. access to food is threatened through losses of income and assets that prejudice ability to buy food; food availability and stability are endangered due to restrictions on movements of people including seasonal workers, closures of schools which are, inter alia, depriving many poor children of publicly provided meals. Lower incomes reduce dietary diversity, intake of micronutrients, and nutritional status, which results in higher risk of adverse health consequences (Laborde et al., 2020, p. 500-502). It has been emphasized in the Committee on World Food Security (CFS) Reform Document of 2009 that the nutritional dimension is integral to the concept of food security (CFS, 2014, p. 2).

The term of nutrition security emerged with the recognition of the necessity to include nutritional aspects into food security in the mid-1990s (CFS, 2012a, p. 6; Pangaribowo, Gerber, \& Torero, 2013, p. 5). This was a positive step towards eradication of malnutrition in all its forms, since malnutrition can have lasting effects on health and productivity. J. Fanzo (2015, p. 17) suggests that the importance of nutrition has been elevated since the nineties not only within the Right to Food doctrine, but also in the UN member state mandates. In 1995, the International Food Policy Research Institute proposed to define nutrition security as "adequate nutritional status in terms of protein, energy, vitamins, and minerals for all household members at all times." The World Bank (WB) (2006, p. 66) has recommended to distinguish between food security and nutrition security since "nutrition security is an outcome of good health, a healthy environment, and good caring practices in addition to household-level food security." Thus, effective functioning of multiple sectors including agriculture, health, education and environment is essential to ensure nutrition security at different levels (household, national, regional, global). In $2012 \mathrm{FAO}$ defined nutrition security as a condition when

all people at all times consume food of sufficient quantity and quality in terms of variety, diversity, nutrient content and safety to meet their dietary needs and food preferences for an active and healthy life, coupled with a sanitary environment, adequate health and care (CFS, 2012b, p. 9).

The following definition of FNS has been adopted in this research: "a condition under which adequate food (quantity, quality, safety, socio-cultural acceptability) is available and accessible for and satisfactorily utilized by all individuals at all times to live a healthy and happy life" (Pangaribowo, Gerber, \& Torero, 2013, p. 5; Weingärtner, 2010). 
The United States Department of Agriculture (USDA), focusing on the issue of household food security, considers that "food insecurity exists whenever the availability of nutritionally adequate and safe foods or the ability to acquire acceptable foods in socially acceptable ways is limited or uncertain" (Coleman-Jensen, 2010, p. 215-216). Nord, Andrews and Carlson (2005, p. 6) in their report developed under USDA indicated that "in households with very low food security, the food intake of some household members was reduced and their normal eating patterns were disrupted because of the lack of money and other resources." The problem is that existing FNS indicators do not take sufficient account of economic dimension of these issues, whereas food prices, non-food prices and income have been identified as key factors for FNS (Pangaribowo, Gerber, \& Torero, 2013, p. 22). Manning (2020) has aptly stated that "food insecurity is complex - there is no silver bullet of policy or market intervention that can lead to a situation where all people at all times will have continuous access to healthy, affordable diets." Although, the formulation of such an objective seems to be intended to mobilize the global community to do its utmost to deliver the first two UN Sustainable Development Goals, namely "no poverty" and "zero hunger" (United Nations Department of Economic and Social Affairs Sustainable Development, 2021).

\section{Research approach}

The methodological approach used in this study was firstly to undertake a narrative literature review to define and outline the challenge of the human right to food and then to analyze quantitative data concerning food security to give some preliminary remarks on the assessment of the realization of the human right to adequate food through the world. The quantitative data was derived from the Economist Intelligence Unit (EIU), FAO, WB, the World Health Organization (WHO), and WFP.

In the first stage of the research, we searched Google Scholar database and Google (to include credible reports) to primarily consider current information on the realization of the human right to food, in other words, ensuring food and nutrition security.

In the second stage of the research, we explored the 2019 GFSI model developed by the EIU. The EIU was founded in 1946 to serve the Economist newspaper and provide business intelligence to outside companies (EIU, 2021b). GFSI is one of the useful quantitative measures to assess the efficiency of the food security system of a given country.

GFSI is a dynamic quantitative and qualitative benchmarking model constructed from 34 indicators grouped into three core categories: food affordability, availability, and finally, quality and safety. Food affordability score "measures the ability of consumers to purchase food, their vulnerability to price shocks and the presence of 
programmes and policies to support customers when shocks occur"; food availability score "measures the sufficiency of the national food supply, the risk of supply disruption, national capacity to disseminate food and research efforts to expand agricultural output"; quality and safety score "measures the variety and nutritional quality of average diets, as well as the safety of food". The baseline index rank is adjusted to reflect the impact that natural resources and resilience have on food security performance of a given country. Natural resources and adjustment score "assesses a country's exposure to the impacts of climate change, its susceptibility to natural resource risks, and how the country is adapting to these risks" (EIU, 2021a). Each of the four categories is composed of sub-categories and further composed of indicators (Table 2; Table 3). All of the scores in the model lie within the range 0 to 100 where $100=$ best. The methodology behind GFSI was developed with consultation from a peer panel of experts coming from the academic, non-profit, and government sectors. Since the realization of the right to food has been evaluated on the basis of the GFSI model, the focus is on ensuring FNS at national level.

Table 2. The baseline Global Food Security Index - 2019 model

\begin{tabular}{|c|c|c|}
\hline \multicolumn{3}{|c|}{ Category/ Sub-category/ Indicator (weight in \%) } \\
\hline 1. Affordability (40\%) & 2. Availability (44\%) & 3. Quality and safety $(16 \%)$ \\
\hline \multirow{2}{*}{$\begin{array}{l}\text { 1.1. Change in average food costs } \\
(22.2 \%)\end{array}$} & 2.1. Sufficiency of supply (23.4\%) & 3.1. Dietary diversity (20.3\%) \\
\hline & 2.1.1. Average food supply & 3.2. Nutritional standards (13.6\%) \\
\hline $\begin{array}{l}\text { 1.2. Proportion of population } \\
\text { under global poverty line ( } 20.2 \%)\end{array}$ & $\begin{array}{l}\text { 2.1.2. Change in dependency } \\
\text { on chronic food aid }\end{array}$ & $\begin{array}{l}\text { 3.2.1. National dietary } \\
\text { guidelines }\end{array}$ \\
\hline $\begin{array}{l}\text { 1.3. Gross domestic product per } \\
\text { capita (US\$ PPP) }(22.2 \%)\end{array}$ & $\begin{array}{l}\text { 2.2. Public expenditure on agri- } \\
\text { cultural R\&D }(8.1 \%)\end{array}$ & $\begin{array}{l}\text { 3.2.2. National nutrition } \\
\text { plan or strategy }\end{array}$ \\
\hline $\begin{array}{l}\text { 1.4. Agricultural import tariffs } \\
(10.1 \%)\end{array}$ & $\begin{array}{l}\text { 2.3. Agricultural infrastructure } \\
(12.6 \%)\end{array}$ & $\begin{array}{l}\text { 3.2.3. Nutrition monito- } \\
\text { ring and surveilance }\end{array}$ \\
\hline $\begin{array}{l}\text { 1.5. Presence and quality of food } \\
\text { safety net programmes ( } 14.1 \%)\end{array}$ & $\begin{array}{l}\text { 2.3.1. Existence of adequate } \\
\text { crop storage facilities }\end{array}$ & $\begin{array}{l}\text { 3.3. Micronutrient availability } \\
(25.4 \%)\end{array}$ \\
\hline $\begin{array}{l}\text { 1.5.1. Presence of food safety-net } \\
\text { programmes }\end{array}$ & $\begin{array}{l}\text { 2.3.2. Road infrastructure } \\
\text { 2.3.3. Port infrastructure }\end{array}$ & $\begin{array}{l}\text { 3.3.1. Dietary availability of } \\
\text { vitamin A }\end{array}$ \\
\hline $\begin{array}{l}\text { 1.5.2. Funding for food safety } \\
\text { net programmes }\end{array}$ & $\begin{array}{l}\text { 2.3.4. Air transport infra } \\
\text { structure }\end{array}$ & $\begin{array}{l}\text { 3.3.2. Dietary availability } \\
\text { of iron }\end{array}$ \\
\hline $\begin{array}{l}\text { 1.5.3. Coverage of food safety } \\
\text { net programmes }\end{array}$ & $\begin{array}{l}\text { 2.3.5. Rail infrastructure } \\
\text { 2.3.6. Irrigation infrastructure }\end{array}$ & $\begin{array}{l}\text { 3.3.3. Dietary availability } \\
\text { of zinc }\end{array}$ \\
\hline $\begin{array}{l}\text { 1.5.4. Operation of food safety- } \\
\text {-net program }\end{array}$ & 2.4. Volatility of agricultural & 3.4. Protein quality (23.7\%) \\
\hline \multirow{4}{*}{$\begin{array}{l}\text { 1.6. Access to financing for far- } \\
\text { mers text }(11.1 \%)\end{array}$} & 2.5. Political stability risk $(9.9 \%)$ & 3.5.1. Agency to ensure the \\
\hline & 2.6. Corruption $(9.9 \%)$ & safety and health of food \\
\hline & 2.7. Urban absorption capacity & 3.5.2. Percentage of popula- \\
\hline & 2.8. Food loss $(12.6 \%)$ & $\begin{array}{l}\text { tion with access to } \\
\text { potable water } \\
\text { 3.5.3. Ability to store food } \\
\text { safely }\end{array}$ \\
\hline
\end{tabular}

Source: own preparation based on (EIU, 2021a). 
Table 3. The GFSI's natural resources \& resilience category - the adjustment factor in 2019 model

\begin{tabular}{|c|c|}
\hline \multicolumn{2}{|c|}{ 4. Natural resources and Resilience } \\
\hline sub-category (weight in \%) & Indicator \\
\hline 4.1. Exposure (21.8\%) & $\begin{array}{l}\text { 4.1.1. Temperature rise } \\
\text { 4.1.2. Drought } \\
\text { 4.1.3. Flooding } \\
\text { 4.1.4. Storm severity (AAL) } \\
\text { 4.1.5. Sea level rise } \\
\text { 4.1.6. Commitment to managing exposure }\end{array}$ \\
\hline 4.2. Water $(14.5 \%)$ & $\begin{array}{l}\text { 4.2.1. Agricultural water risk - quantity } \\
\text { 4.2.2. Agricultural water risk - quality }\end{array}$ \\
\hline 4.3. Land $(14.5 \%)$ & $\begin{array}{l}\text { 4.3.1. Land degradation } \\
\text { 4.3.2. Grassland } \\
\text { 4.3.3. Forest change }\end{array}$ \\
\hline 4.4. Oceans $(12.7 \%)$ & $\begin{array}{l}\text { 4.4.1. Ocean eutrophication } \\
\text { 4.4.2. Marine biodiversity } \\
\text { 4.4.3. Marine protected areas }\end{array}$ \\
\hline 4.5. Sensitivity (10.9\%) & $\begin{array}{l}\text { 4.5.1. Food import dependency } \\
\text { 4.5.2. Dependence on natural capital } \\
\text { 4.5.3. Disaster risk management }\end{array}$ \\
\hline 4.6. Adaptive capacity (18.2\%) & $\begin{array}{l}\text { 4.6.1. Early warning measures/climate } \\
\text { smart ag } \\
\text { 4.6.2. National agricultural risk manage- } \\
\text { ment system }\end{array}$ \\
\hline 4.7. Demographic stresses (7.3\%) & $\begin{array}{l}\text { 4.7.1. Population growth }(2015-20) \\
\text { 4.7.2. Urbanisation }(2015-20)\end{array}$ \\
\hline
\end{tabular}

Source: own preparation based on (EIU, 2021a).

\section{Results}

Exploring the GFSI model, it can be noted that the elements related to nutrition are of minor importance (dietary diversity - 3.25\%; nutritional standards $1.36 \%$; micronutrient availability $-4.1 \%$; protein quality $-3.792 \%$ ) thus they make only a rather small contribution to the overall score. We find it puzzling as malnutrition affects most of the world's population, all geographies, all age groups, rich and poor, men and women. There are many forms of malnutrition: from undernutrition, stunting and wasting in children under five, micronutrient deficiencies, moderate and severe thinness or underweight in adults, and conversely overweight and obesity in both children and adults (Kowalska, \& Manning, 2021, p. 909). After years of progress, global hunger levels have been rising since 2015 (FAO et al., 2019, p. 16). The number of undernourished people in Sub-Saharan Africa and South Asia is on the rise, and at the same 
time, the number of overweight and obese people is growing in North America and Europe. Overweight and obesity used to be considered as a high-income countries problem, but it is on the rise in low- and middle-income countries, particularly in urban areas (WHO, 2020). Manning and Kelly (2020, p. 8) have pointed out that poor nutrition (both under and over consumption of calories) is a particular issue for low-income households. In 2016, at a global level, 9.4\% of adult women and $8.6 \%$ of adult men were underweight, whereas, $39.2 \%$ of adult women and $38.5 \%$ of adult men were overweight (including the obese). In 2016,39\% of adults aged 18 years and over were overweight and 13\% of the world's adult population were obese. The worldwide prevalence of obesity among adults nearly tripled between 1975 and 2016. While just 4\% of children and adolescents aged 5-19 were overweight in 1975, over 18\% of children and adolescents were overweight in 2016 (WHO, 2020). Since 2000, the prevalence of overweight in both children and adolescents group and adults group has been on the rise (Chart 1) and it is difficult to envisage a reversal of this trend. The global economic impact of obesity has been increasing; up to 20 percent of all healthcare spending is attributable to obesity, through related diseases such as type 2 diabetes and heart disease (Dobbs, \& Manyika, 2015, p. 44). Furthermore, reversing the obesity epidemic would lessen the burden on healthcare systems, as obesity is not only one of the costliest health conditions but also a major risk of COVID-19 hospitalisations and complications. Unfortunately, lockdown hinders engagement of people in regular physical activity which is crucial for maintaining healthy body weight.

Since both underweight and overweight "kill" people and cost the economy a great deal of money, and the number of overweight people is more than four times the number of underweight individuals, it is time to modify the existing FNS indicators. The value of an accurate FNS indicator could send a strong signal to policymakers to intensify their activities in making regular physical activity and healthier dietary choices available, affordable and easily accessible to everyone, particularly to the poorest individuals. In this respect it should be highlighted that the GFSI is still of considerable value. 
Chart 1. Prevalence of overweight in children and adolescents aged 5-19 years and adults aged 18 years and over from 2000 to 2016 (a percentage of the population)

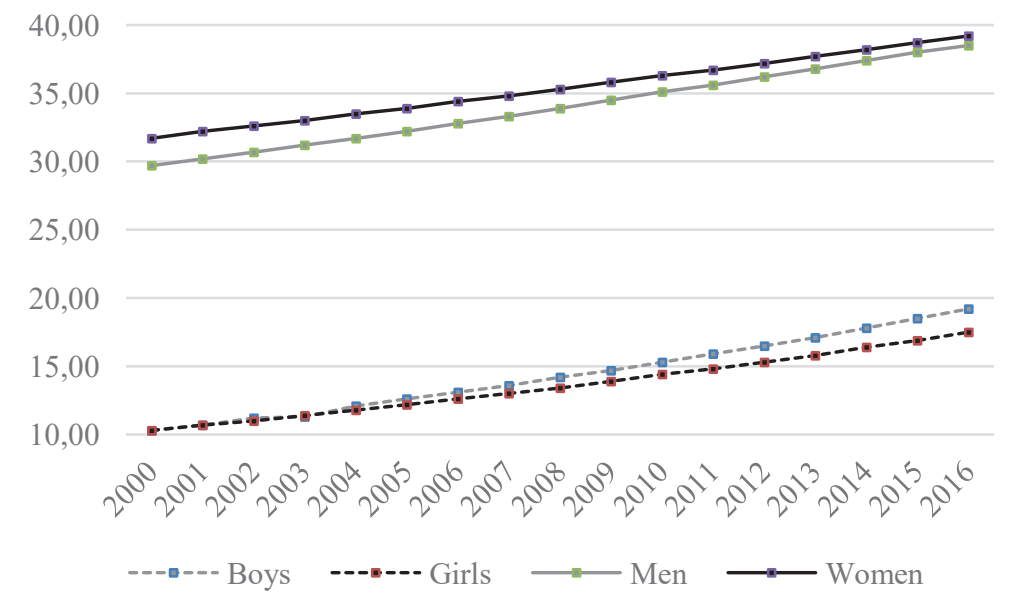

Source: own preparation based on (Global Nutrition Report, 2020a).

In 2019 out of 113 countries, Singapore (87.4), Ireland (84.0), USA (83.7), Switzerland (83.1), Finland (82.9) and Norway (82.9) scored the highest overall GFSI. Among the European countries Ireland rated first in terms of affordability, Switzerland scored the highest availability indicator, and Finland was ahead in terms of food quality and safety. The Czech Republic rated first in terms of natural resources and resilience. Ukraine (57.1), Serbia (62.8), Bulgaria (66.2) and Slovakia (68.3) scored the lowest GFSI value among the European countries taken into consideration at the ranking stage (Chart 2). The bottom five countries with the lowest GFSI in the world were Venezuela (31.2), Burundi (34.3), Yemen (35.6), the Democratic Republic of Congo (35.7), Chad (36.9) (EIU, 2021a).

The overall food security score (average of the 113 countries included in GFSI) decreased from 60.72 in 2019 to 60.44 in 2020. Comparison of the country-specific index values of 2019 with the figures of 2020 reveals that the food security situation in more than half of the countries considered (55.8\%) has probably deteriorated during the pandemic. The countries whose overall GFSI scores have declined the most when comparing 2020 to 2019 include: Norway (GFSI score fell by 4.4 percentage points), Egypt (4.3 percentage points), Colombia (4.2), Guinea (3.1), Chile (2.8), Brazil (2.5), Nigeria (2.4), Sierra Leone (2.4), Sweden (2.4), and Argentina (2.4). There were also 49 countries whose overall GFSI scores have increased when comparing 2020 to 2019. The countries whose scores have increased the most are Haiti (GFSI score rose by 4.7 percentage points), 
Kazakhstan (2.7 percentage points), Ukraine (2.7), Pakistan (2.6), Romania (2.6), Paraguay (2.3), Mozambique (1.9), Nepal (1.8), Bulgaria (1.7), and Angola (1.6). Analysis of the country-specific GFSI scores might be the starting-point for further studies aimed at obtaining an accurate and complete picture of the food and nutrition security situation in the world and making assessment of changes to the situation over time.

Chart 2. Food security performance of the European countries in 2019

The Global Food Security Index
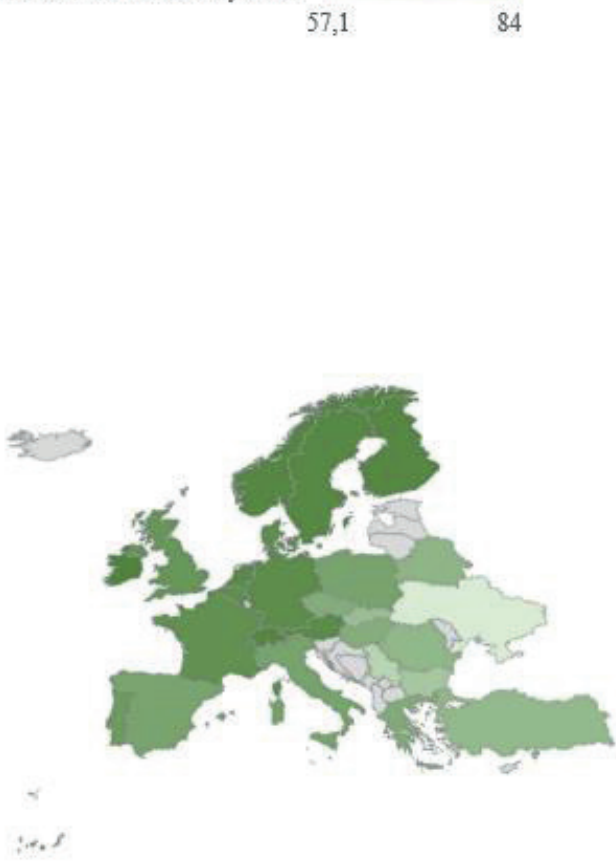

Obstughwane przez ushige Bing

Source: own preparation based on (EIU, 2021a).

The performance of any country based on its food security score might be compared with the leaders to identify areas for improvements. Take Poland, for example, which rated $24^{\text {th }}$ in the 2019 GFSI ranking. This time, the country was ranked $10^{\text {th }}$ 
in terms of natural resources and adjustment. However, Poland is at risk of particularly high levels of exposure to flooding and drought, and is highly dependent on certain food imports. Poland enjoyed high rates in some fields, i.e. proportion of population under global poverty line (100), presence and quality of food safety net programs (100), access to financing for farmers (100), change in average food costs (99) which affected food affordability; urban absorption capacity (91) and food loss (91) affecting availability; nutritional standards (100) and food safety (99) affecting food quality and safety. In order to assess the gap in food security performance of Poland and Singapore, which is the world leader, the three core scores for each country have been compared (Chart 3). There is still much room for improvement in the area of food affordability and food availability in Poland. Poland needs to tackle weaknesses in the following areas: level of gross domestic product per capita (23) which affects food affordability; lack of political stability (47), high level of corruption (50), and poor condition of agricultural infrastructure (64) (particularly irrigation infrastructure and road infrastructure), all three affecting food availability. Apart from the fact that food quality and safety scores for Poland and Singapore are at the same level (Chart 3), another 21 countries including, inter alia, Finland, Norway, Sweden, USA, Netherlands, Portugal, Ireland, Denmark, France, Canada and Greece have scored higher (EIU, 2021a).

Chart 3. Food security performance of Poland and Singapore in 2019 - comparing indicators of affordability, availability and quality \& safety
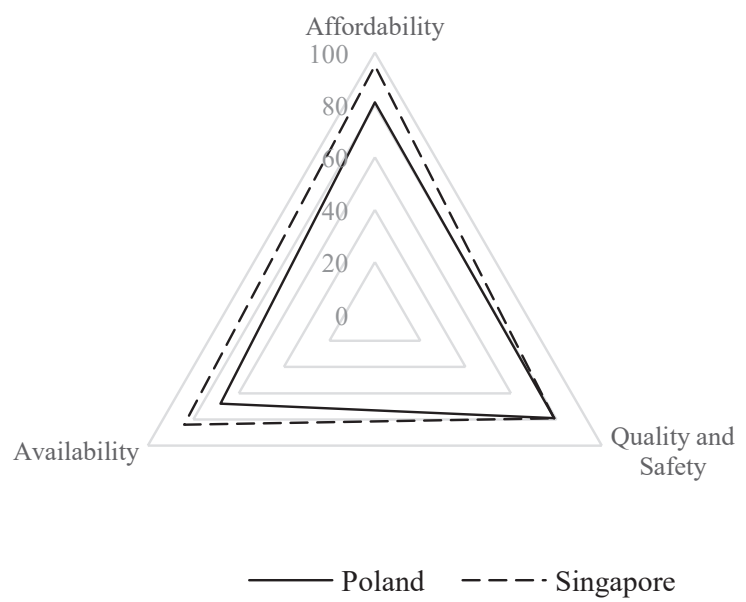

Source: own preparation based on (EIU, 2021a). 


\section{Conclusion}

The presence of the right to food in numerous legal acts regulating human rights under international and regional law confirms the fundamental nature of this right. The State Signatories to the international agreements concluded in the latter part of the 20th century have had the obligation to protect, respect and fulfill the right to food. However, in the past few years several countries have been distancing from the desired objective of ensuring FNS for all. Furthermore, during the COVID-19 pandemic, the number of malnourished people including underweight individuals and the overweight has been increasing. COVID-19 threatens FNS mainly through losses of income and food price spikes resulting in lower nutritional status of people (FAO, 2021, p. 1). Nonetheless, the national GFSI score has increased in more than $40 \%$ of the countries included in the index when comparing 2020 to 2019. Thus, further studies on the food and nutrition security situation in these countries are needed. Analysis of national GFSI scores might be a good start for comprehensive research on the realization of the human right to food through the world.

The EIU supplies food security data that enables a comparative analysis of countries included in GFSI which might result, inter alia, in the indication of areas where improvements are needed. The point is to review the methodology behind existing food security indicators and take account of the fact that the problem of obesity and overweight is even more urgent than the world hunger issue. The weights of the GFSI elements related to nutrition should be increased. An informative value of a revised indicator and its sub-indicators would be greater for the state taking steps to realize the right to food. An accurate FNS indicator could send a strong signal to the policymakers to reorient current measures and activities.

\section{References}

Acosta Market Research. (2020). New Acosta report details how COVID-19 is reinventing how America eats. Retrieved from https://www.acosta.com/news/new-acostareport-details-how-covid-19-is-reinventing-how-america-eats (1.12.2021).

Carletto, C., Zezza, A., \& Banerjee, R. (2013). Towards better measurement of household food security: Harmonizing indicator and the role of household surveys. Global Food Security, 2(1), 30-40. doi: 10.1016/j.gfs.2012.11.006

CESCR General Comment No. 12: The Right to Adequate Food (Art. 11). (1999). Retrieved from https://www.refworld.org/pdfid/4538838cl1.pdf (18.02.2021). 
Chammem, N., Issaoui, M., Dâmaso de Almeida, A.I., \& Martins Delgado, A. (2018). Food Crises and Food Safety Incidents in European Union, United States, and Maghreb Area: Current Risk Communication Strategies and New Approaches. Journal of AOAC International, 101(4), 923-938. doi: 10.5740/jaoacint.17-0446 Committee on World Food Security (CFS). (2012a). Coming to Terms with Food Security, Nutrition Security, Food Security and Nutrition, Food and Nutrition Security. Retrieved from http://www.fao.org/docrep/meeting/026/MD776E.pdf(5.01.2021). Committee on World Food Security (CFS). (2012b). Coming to Terms with Terminology. Retrieved from http://www.fao.org/fileadmin/templates/cfs/Docs1112/CFS39Docs/ CFS_FSN_Terminology_16_October_2012.pdf (5.01.2021).

Committee on World Food Security (CFS). (2014). Global Strategic Framework for Food Security \& Nutrition (GSF). Retrieved from http://www.fao.org/fileadmin/templates/cfs/Docs1314/GSF/GSF_Version_3_EN.pdf (5.01.2021).

Council of Europe. (2021). The International Covenant on Economic, Social and Cultural Rights. Retrieved from https://www.coe.int/en/web/compass/international-covenant-on-economic-social-and-cultural-rights (19.01.2021).

Coleman-Jensen, A.J. (2010). U.S. Food Insecurity Status: Toward a Refined Definition. Social Indicators Research, 95(2), 215-230. doi: 10.1007/s11205-009-9455-4

Dobbs, R., \& Manyika, J. (2015). The obesity crisis. How to fight a scourge as damaging to the global economy as war. Cairo Review, 18, 44-57. Retrieved from https:// www.thecairoreview.com/wp-content/uploads/2015/09/CR18-Dobbs-Manyika. pdf (13.01.2021).

Economist Intelligence Unit (EIU). (2021a). Global Food Security Index. Retrieved from https://foodsecurityindex.eiu.com/ (12.01.2021).

Economist Intelligence Unit (EIU). (2021b). Our story. Retrieved from https://www.eiu. com/n/about/our-story/ (11.01.2021).

E.I.T. Food. (2020). COVID-19 impact on consumer food behaviours in Europe. Retrieved from https://www.eitfood.eu/media/news-pdf/COVID-19_Study_-_European_Food_Behaviours_-_Report.pdf (29.11.2021).

Espitia, A., Rocha, N., \& Ruta, M. (2020). Covid-19 and Food Protectionism: The Impact of the Pandemic and Export Restrictions on World Food Markets (May 19, 2020). World Bank Policy Research Working Paper No. 9253. Retrieved from https://ssrn. com/abstract=3605887 (30.11.2021).

Fanzo, J. (2015). Ethical issues for human nutrition in the context of global food security and sustainable development. Global Food Security, 7, 15-23. doi: 10.1016/j.gfs.2015.11.001

Food and Agricultural Organisation (FAO). (2021). FAO's Response to COVID-19: Building to transform. Retrieved from https://www.fao.org/3/ng635en/ng635en.pdf (30.11.2021). 
FAO, IFAD, UNICEF, WFP and WHO. (2019). The State of Food Security and Nutrition in the World 2019. Safeguarding against economic slowdowns and downturns. Retrieved from http://www.fao.org/3/ca5162en/ca5162en.pdf (18.11.2020).

Global Nutrition Report. (2020a). The 2020 Global Nutrition Report. Action on equity to end malnutrition. Retrieved from https://globalnutritionreport.org/ reports/2020-global-nutrition-report/2020-global-nutrition-report-context-covid-19/ (13.01.2021).

Global Nutrition Report. (2020b). The 2020 Global Nutrition Report in the context of Covid-19. Retrieved from https://globalnutritionreport.org/reports/2020-global-nutrition-report/ (22.12.2020).

Grunert, K.G., Janssen, M., Christensen, R.N., Teunissen, L., Cuykx, I., Decorte, P., Lucia A., \& Reisch, L.A. (2022). “Corona Cooking”: The interrelation between emotional response to the first lockdown during the COVID-19 pandemic and cooking attitudes and behaviour in Denmark. Food Quality and Preference, 96, 104425. doi: 10.1016/j.foodqual.2021.104425

Hepburn, J., Laborde, D., Parent, M., \& Smaller, C. (2020). COVID-19 and Food Export Restrictions: Comparing today's situation to the 2007/08 price spikes. Retrieved from https://www.iisd.org/system/files/2020-08/covid-19-food-export-restrictions.pdf (29.11.2021).

Heyns, C., \& Killander, M. (2011). Toward Minimum Standards for Regional Human Rights Systems. In: H. Mahnoush, J. Cogan, R. Sloane, \& S. Wiessner (Eds.), Looking to the Future (pp. 527-558). Lejda: Brill Nijhoff. doi: 10.1163/9789047427070_030

Hospes, O., \& van der Meulen, B. (2009). Fed up with the right to food? The Netherlands' Policies and Practices regarding the human right to adequate food. Wageningen: Wageningen Academic Publishers.

International Committee of the Red Cross (ICRC). (2021a). Convention (III) relative to the Treatment of Prisoners of War. Geneva, 12 August 1949. Retrieved from https:// ihl-databases.icrc.org/ihl/full/GCIII-commentary (19.01.2021).

International Committee of the Red Cross (ICRC). (2021b). Geneva Convention for the Amelioration of the Condition of the Wounded and Sick in Armed Forces in the Field (First Geneva Convention), 12 August 1949, 75 UNTS 31. Retrieved from https://www.refworld.org/docid/3ae6b3694.html (19.01.2021).

International Committee of the Red Cross (ICRC). (2021c). Protocol Additional to the Geneva Conventions of 12 August 1949, and relating to the Protection of Victims of International Armed Conflicts (Protocol I), 8 June 1977. Retrieved from https:// ihl-databases.icrc.org/ihl/INTRO/470 (19.01.2021).

International Monetary Fund (IMF). (2020). IMF Annual Report. A year like no other. Retrieved from https://www.imf.org/external/pubs/ft/ar/2020/eng/ (4.01.2021). 
Kalinowski, M. (2019). Human rights should be our business. Economics and Law, 18(4), 459-473. doi: 10.12775/EiP.2019.030

Kowalska, A. (2019). Ekonomiczne problemy fałszowania żywności. Instrumenty przeciwdziałania [Economic problems of food adulteration. Prevention measures]. Lublin: The Publishing House of Maria Curie-Skłodowska University.

Kowalska, A., \& Manning, L. (2021). Using the rapid alert system for food and feed: potential benefits and problems on data interpretation. Critical Reviews in Food Science and Nutrition, 61(6), 906-919. doi: 10.1080/10408398.2020.1747978

Kowalski, J. (2020). The right to water as a fundamental human right in Poland and worldwide. International Journal of Human Rights and Constitutional Studies, 7(3), 233-246. doi: 10.1504/IJHRCS.2020.109251

Laborde, D., Martin, W., Swinnen, J., \& Vos, R. (2020). COVID-19 risks to global food security. Science, 369(6503), 500-502. doi: 10.1126/science.abc4765

Manning, L. (2021). Safeguarding global supply chains during a pandemic. Nature Food, 2, 10. doi: 10.1038/s43016-020-00213-5

Manning, L., \& Kelly, J. (2020). Obesity: locating social responsibility in the context of evolving norms. International Journal of Innovation and Sustainable Development, 14(1), 8-29. doi: 10.1504/IJISD.2020.104241

Nord, M., Andrews, M., \& Carlson, S. (2005). Household food security in the United States, 2005. Retrieved from https://www.ers.usda.gov/webdocs/publications/45655/29206_err29_002.pdf?v=41334 (10.01.2021).

Organization of American States (OAS). (2021). Additional Protocol to the American Convention on Human Rights in the Area of Economic, Social and Cultural Rights. Retrieved from https://www.oas.org/juridico/english/treaties/a-52.html (19.01.2021).

Osiatyński, W. (2011). Prawa człowieka i ich granice [Human rights and their borders]. Kraków: Społeczny Instytut Wydawniczy Znak.

Pangaribowo, E.H., Gerber, N., \& Torero, M. (2013). Food and Nutrition Security Indicators: A Review. ZEF Working Paper, 108. doi: 10.2139/ssrn.2237992

Pinstrup-Andersen, P. (2009). Food Security: Definition and Measurement. Food Security, 1, 5-7. doi: 10.1007/s12571-008-0002-y

Roosevelt, F.D. (1941). The Four Freedoms. Retrieved from https://www.americanrhetoric. com/speeches/fdrthefourfreedoms.htm (5.01.2021).

Sachs, J., Schmidt-Traub, G., Kroll, C., Lafortune, G., Fuller, G., \& Woelm, F. (2020). The Sustainable Development Goals and COVID-19. Sustainable Development Report 2020. Cambridge: Cambridge University Press.

Srogosz, T. (2020). Międzynarodowe prawo żywnościowe [International food law]. Warszawa: Wydawnictwo C.H.Beck. 
United Nations (UN). (2021). The Universal Declaration of Human Rights. Retrieved from https://www.un.org/en/universal-declaration-human-rights/index.html (15.01.2021).

United Nations Department of Economic and Social Affairs Sustainable Development. (2021). The 17 goals. Retrieved from https://sdgs.un.org/goals (5.01.2021).

United Nations Office of the High Commissioner for Human Rights (UN OHCHR). (2010). The right to adequate food. Fact Sheet No. 34. Retrieved from https://www.ohchr. org/Documents/Publications/FactSheet34en.pdf (22.12.2020).

United Nations Office of the High Commissioner for Human Rights (UN OHCHR). (2021a). Convention on the Rights of the Child. Retrieved from https://www. ohchr.org/en/professionalinterest/pages/crc.aspx?fbclid=IwAR35cVUouzhmgWieqVBgZYcB2B0AxOmow0WCMu4zy7eIWfQD-VMAwGkORks (19.01.2021).

United Nations Office of the High Commissioner for Human Rights (UN OHCHR). (2021b). International Covenant on Economic, Social and Cultural Rights Adopted and opened for signature, ratification and accession by General Assembly resolution 2200A (XXI) of 16 December 1966 entry into force 3 January 1976, in accordance with article 27. Retrieved from https://www.ohchr.org/EN/ProfessionalInterest/ Pages/CESCR.aspx (15.01.2021).

Weingärtner, L. (2010). The Concept of Food and Nutrition Security. In: K. Klennert (Ed.), Achieving Food and Nutrition Security: actions to meet the global challenge A training course reader (3rd Edition) (pp. 21-51). Bonn: Inwent.

World Bank (WB). (2006). World Bank. 2006. Repositioning Nutrition as Central to Development: A Strategy for Large Scale Action. Retrieved from https://openknowledge. worldbank.org/bitstream/handle/10986/7409/347750PAPER0Re101OFFICIAL0USE0ONLY1.pdf? sequence=1\&isAllowed $=y$ (5.01.2021).

World Bank (WB). (2021). Individuals using the Internet (\% of population). Retrieved from https://data.worldbank.org/indicator/IT.NET.USER.ZS (18.01.2021).

World Food Programme (WFP). (2006). World Hunger Series - Hunger and Learning. Retrieved from https://docs.wfp.org/api/documents/WFP-0000118955/ download/?_ga=2.204717527.691528589.1609848723-1064141307.1609848723 (5.01.2021).

World Health Organization (WHO). (2020). Obesity and overweight. Retrieved from https://www.who.int/news-room/fact-sheets/detail/obesity-and-overweight (13.01.2021).

\section{Summary}

Human rights have been experiencing a cautious renaissance recently. They are subject to multi-level protection (international, regional, national level). Human rights are universal 
moral laws of a basic nature, belonging to every individual in his contacts with the state. The realization of the right to food differs within existing law systems, political systems or socio-economic systems in world regions. There is a significant role of the state in implementing human right to food and ensuring food and nutrition security (FNS). The aim of this paper is to analyze the realization of the right to food in different countries and to identify challenges of interpreting and then acting upon the value of the Global Food Security Index (GFSI). The number of undernourished people in Sub-Saharan Africa and South Asia is on the rise, and the number of overweight people in North America and Europe is growing. During the Covid-19 pandemic, as a result of lockdown, the number of malnourished people including overweight individuals and the underweight has been increasing. Covid-19 threatens global food security mainly through food price spikes and losses of income resulting in lower nutritional status of people. The number of overweight people is more than four times the number of underweight individuals on a global scale. The problem is that the bulk of existing FNS indicators reflects the issue of underconsumption of calories, but does not reflect the obesity issue. The methodology behind GFSI needs to be revised and the issue of increasing weights of the GFSI elements related to nutrition should be reconsidered.

KEYwords: human rights, right to food, food and nutrition security, Global Food Security Index (GFSI).

\section{Streszczenie}

Prawa człowieka w ostatnich latach przeżywają pewien renesans. Są one przedmiotem ochrony na poziomie międzynarodowym, regionalnym i krajowym. Prawa człowieka są to powszechne prawa moralne o podstawowym charakterze, przysługujące każdej jednostce w kontaktach z państwem. Realizacja prawa człowieka do żywności różni się w poszczególnych regionach świata, gdzie funkcjonują odmienne systemy prawa, systemy polityczne czy systemy społecznogospodarcze. Istotna jest rola państwa w realizacji prawa człowieka do żywności oraz zapewnieniu bezpieczeństwa żywnościowego i żywieniowego. Celem pracy jest analiza realizacji prawa do żywności w różnych krajach oraz określenie wyzwań związanych z interpretacją wartości globalnego wskaźnika bezpieczeństwa żywnościowego (Global Food Security Index, GFSI). Liczba osób niedożywionych zwiększa się w Afryce Subsaharyjskiej i Południowej Azji, a jednocześnie rośnie udział osób z nadwagą w Ameryce Północnej i Europie. Podczas pandemii COVID-19, na skutek lockdownu, problemy te nasiliły się. COVID-19 zagraża globalnemu bezpieczeństwu żywnościowemu głównie z powodu wzrostu cen i utraty dochodów skutkujących pogorszeniem się stanu odżywienia ludzi. Na świecie jest cztery razy więcej osób z nadwagą niż tych z niedowagą. Problem w tym, że wiele wskaźników pomiaru bezpieczeństwa żywnościowego i żywieniowego odzwierciedla kwestię niewystarczającego spożywania kalorii, a nie pokazuje problemu otyłości. Metodyka, na podstawie której liczony jest wskaźnik GFSI, powinna być zrewidowana. Należy ponownie przemyśleć wagi elementów wskaźnika związanych z żywieniem.

SŁowA KLUCzowe: prawa człowieka, prawo do żywności, bezpieczeństwo żywnościowe i żywieniowe, Globalny Wskaźnik Bezpieczeństwa Żywnościowego (GFSI). 
Funding: This work was supported by grant of National Science Centre, Poland, no 2020/39/D/HS4/01280.

\section{Noty o autorach}

Jarosław Kowalski - M.A., attorney at law, a PhD student at the Doctoral School of Social Sciences at Maria Curie-Skłodowska University in Lublin, Poland. He is an expert in the area of human rights protection and food law; e-mail: jaroslaw.kowalski@poczta.umcs.lublin.pl; ORCID: 00000002-4731-1928.

Aleksandra Kowalska - Dr habil., Prof. UMCS, Department of Microeconomics and Applied Economics, Institute of Economics and Finance, Maria Curie-Skłodowska University. She is an expert the area of protecting integrity of food supply chain from fraud and adulteration. Her expertise is also in the area of food security, food policy and governance, and sustainable food systems; e-mail: aleksandra.kowalska@mail.umcs.pl; ORCID: 0000-0003-3854-951X. 
